\section{Quantifying the pH-Response of a Peat-based Medium to Application of Basic Chemicals}

\author{
A. Jeremy Bishko ${ }^{1}$ and Paul. R. Fisher ${ }^{2}$ \\ Department of Plant Biology, University of New Hampshire, Durham, \\ NH 03824
}

\author{
William R. Argo \\ Blackmore Company, Belleville, MI 48111
}

Additional index words. calcium hydroxide, flowable lime, potassium bicarbonate, potassium hydroxide, soilless medium, water-soluble fertilizer

\begin{abstract}
The objective was to systematically quantify the dose response from applications of several alkaline materials recommended for raising $\mathrm{pH}$ in acidic media. A 70 peat : 30 perlite (by volume) medium was mixed with a pre-plant nutrient charge, a wetting agent, and between 0 and $1.5 \mathrm{~kg} \cdot \mathrm{m}^{3}$ of a dolomitic hydrated lime resulting in six starting-pHs between 3.4 and 6.4. The supernatant from a solution of $\mathrm{Ca}(\mathrm{OH})_{2}, 2.5$ to 40 $\mathrm{mL} \cdot \mathrm{L}^{-1}$ of a flowable dolomitic limestone suspension, $99.5 \% \mathrm{KHCO}_{3}$ between 0.6 to 9.6 $\mathrm{g} \cdot \mathrm{L}^{-1}, 85 \% \mathrm{KOH}$ between 0.056 and $0.56 \mathrm{~g} \cdot \mathrm{L}^{-1}, 15 \mathrm{~N}-0 \mathrm{P}-12 \mathrm{~K}$ water-soluble fertilizer at 50 to $400 \mathrm{mg} \cdot \mathrm{L}^{-1} \mathrm{~N}$, and a distilled water control were applied at $60 \mathrm{~mL}$ per $126-\mathrm{mL}$ container with minimal leaching as a single drench (except the $15 \mathrm{~N}-0 \mathrm{P}-12 \mathrm{~K}$ that was applied about every three days). All chemicals increased medium-pH within one day, and $\mathrm{pH}$ remained stable until day 28 except for $\mathrm{Ca}(\mathrm{OH})_{2}$ which showed a 0.2 unit decrease in $\mathrm{pH}$ from day 1 to 28 . The $\mathrm{Ca}(\mathrm{OH})_{2}$ and $\mathrm{KOH}$ drenches raised medium-pH by less than 0.5 units, and there was a slight decrease in $\mathrm{pH}$ from the $15 \mathrm{~N}-0 \mathrm{P}-12 \mathrm{~K}$ for starting-pHs lower than 5.0. Flowable dolomitic lime and $\mathrm{KHCO}_{3}$ raised $\mathrm{pH}$ by up to $2 \mathrm{pH}$ units, averaged across starting $\mathbf{p H s}$ and 1-28 days after application. The effect on medium-pH increased as concentration of flowable lime and $\mathrm{KHCO}_{3}$ increased. Effect of flowable lime was greater (up to 2.9 units) at lower starting-pHs, whereas $\mathrm{KHCO}_{3}$ was less affected by starting-pH. Medium-EC increased by $<0.6 \mathrm{dS} \cdot \mathrm{m}^{-1}$ following single applications of all solutions.
\end{abstract}

In container plant production, medium-pH affects micronutrient solubility and plant availability (Biernbaum and Argo, 1995; Peterson, 1981). If medium-pH is too low, excessive levels of nutrients (mainly $\mathrm{Fe}$ and $\mathrm{Mn}$ ) may accumulate in plant tissue causing damage to the crop (Koranski and Kessler, 1996; Nelson, 1998).

When medium-pH is found to be below the optimum range, rapid amelioration is necessary to prevent crop damage. Chemicals suggested for raising $\mathrm{pH}$ in media include nitratebased water-soluble fertilizer, $\mathrm{Ca}(\mathrm{OH})_{2}$, $\mathrm{CaCO}_{3}, \mathrm{KOH}, \mathrm{KHCO}_{3}$, and $\mathrm{NaHCO}_{3}$ (Bailey, 1996; Cox, 1999; Elliott, 1994). Although these materials have been recommended to greenhouse growers for correcting low medium- $\mathrm{pH}$, recommended rates often include a broad range with little or no information on

Received for publication 30 Oct. 2000. Accepted for publication 5 July 2001. We thank the Bedding Plants Foundation, GreenCare Fertilizers, The Scotts Company, Sun Gro Horticulture, and the UNH Agricultural Experiment Station for supporting this project. Scientific contribution 2071 of the UNH Agricultural Experiment Station. The use of trade names in this publication does not imply endorsement of the products named or criticism of similar ones not mentioned.

${ }^{1}$ Graduate Research Assistant

${ }^{2}$ Assistant Professor. To whom reprint requests should be addressed. dose-response effects (Bailey, 1996). Researchers have quantified the dose response of several materials to peat-based media and field soils (Elliott 1994; Jarrell et al., 1979; McNab and Jerie, 1989). A comparison between alkaline materials applied under standard conditions is lacking, however, for peat-based media.

The objectives of this experiment were to: 1) quantify and compare the $\mathrm{pH}$-response for a 70 peat : 30 perlite medium following application of several basic chemicals under standardized conditions; and 2) determine how $\mathrm{pH}$ changed over time following the chemical application. In addition, the effect of initial medium-pH on dose response, the equivalency of $\mathrm{pH}$-response for various chemicals, and their effects on growing-medium electroconductivity (EC) were determined. No plants were included in this experiment to eliminate the variable of plant interaction with medium and chemical application.

\section{Materials and Methods}

Root medium. The root medium used was (by volume) $70 \%$ Canadian sphagnum peat (Fisons professional black bale peat; SunGro Horticulture, Bellevue, Wash.) with long fibers and little dust (Von Post scale 1-2; Puustjarvi and Robertson, 1975), and 30\% coarse perlite.
Six 126-mL containers $(5.5-\mathrm{cm}$ width $\times$ 6.1-cm length $\times 7.4-\mathrm{cm}$ depth) were filled with the peat: perlite medium. Medium in the containers was irrigated twice with excess water at 30-min intervals, allowed to drain for $60 \mathrm{~min}$, and then weighed. The containers were then placed in a drying oven at $105^{\circ} \mathrm{C}$ for $72 \mathrm{~h}$ and weighed again. Container waterholding capacity was estimated to be the difference between the drained weight and the oven dried weight. At container capacity, the medium held $79 \mathrm{~mL}$ of water per container.

At mixing, $0.6 \mathrm{~kg} \cdot \mathrm{m}^{-3}$ of a commercial $6 \mathrm{~N}-3 \mathrm{P}-7 \mathrm{~K}-10 \mathrm{Ca}-1 \mathrm{Mg}$ pre-plant nutrient charge [composed of commercial-fertilizer grade $\mathrm{KNO}_{3}, \mathrm{Ca}\left(\mathrm{NO}_{3}\right)_{2}$, gypsum, triple superphosphate, and $\mathrm{MgSO}_{4}$ (GreenCare, Chicago)] and a wetting agent (Aquagro $2000 \mathrm{~L}$; Aquatrols, Pennsaulken, N.J.) at $0.2 \mathrm{~L} \cdot \mathrm{m}^{-3}$ were added. A range of initial medium-pHs were achieved by incorporating 0.0, 0.3, 0.6, $0.9,1.2$, or $1.5 \mathrm{~kg} \cdot \mathrm{m}^{-3}$ of a dolomitic hydrated lime $\left[97 \% \mathrm{Ca}(\mathrm{OH})_{2} \cdot \mathrm{MgO}\right.$, National Lime and Stone, Findlay, Ohio] in which $92 \%$ of the lime passed through a $45-\mu \mathrm{m}$ screen. The initial pHs of the lime treatments were 3.38, $3.90,4.37,5.03,5.79$, and 6.40, respectively. After mixing, medium from each lime treatment remained in plastic bags with the tops open to the air for gas exchange for $7 \mathrm{~d}$ at $17.7^{\circ} \mathrm{C}$ (root-medium temperature) before the 126-mL containers were filled.

Basic chemical treatments. A saturated solution of analytical grade $\mathrm{Ca}(\mathrm{OH})_{2}$ was prepared by mixing $25 \mathrm{~g} \mathrm{Ca}(\mathrm{OH})_{2}$ per $\mathrm{L}$ of distilled water. After the solution was allowed to equilibrate overnight at $19^{\circ} \mathrm{C}$, the supernatant solution was drained off and used in the experiment. Flowable dolomitic limestone (FDL) (LimeStone-F; W.A. Cleary Corp., Dayton, N.J.), which is formulated as a slurry, was thoroughly mixed and added to distilled water at 2.5, 5.0, 10.0, 20.0, and $40 \mathrm{~mL} \cdot \mathrm{L}^{-1}$. Other chemical treatments (Table 1) were dissolved in distilled water before application to the medium, and included reagent-grade $\mathrm{KHCO}_{3}$, reagent-grade $\mathrm{KOH}$, and a commercial watersoluble fertilizer [ $15 \mathrm{~N}-0 \mathrm{P}-12 \mathrm{~K}$, composed of commercial-fertilizer grade $\mathrm{KNO}_{3}, \mathrm{Ca}\left(\mathrm{NO}_{3}\right)_{2}$, $\mathrm{NH}_{4} \mathrm{NO}_{3}$ and with $90 \%$ of $\mathrm{N}$ in the nitrate form (GreenCare, Chicago)].

Solution $\mathrm{pH}, \mathrm{EC}$, and milliequivalents of $\mathrm{CaCO}_{3}$ per liter of each treatment are presented in Table 1. Milliequivalents per liter (meq. $\mathrm{L}^{-1}$ ) of $\mathrm{CaCO}_{3}$ in Table 1 were calculated based on the formula from Bailey (1996), p.73. Calculations of meq. $\mathrm{L}^{-1}$ for flowable lime, $\mathrm{KHCO}_{3}$, and $\mathrm{KOH}$ were calculated from atomic weights and solution concentrations, whereas milliequivalents for the supernatant of $\mathrm{Ca}(\mathrm{OH})_{2}$ was calculated from the $\mathrm{pH}$-difference between distilled water and the supernatant solution. Milliequivalents were not calculated for $15 \mathrm{~N}-0 \mathrm{P}-12 \mathrm{~K}$ because the solution $\mathrm{pH}$ was lower than the distilled water $\mathrm{pH}$.

On 25 Jan. 1998, containers were arranged randomly on mesh benches in a well-ventilated glass greenhouse. During the experiment, medium and air temperature averaged $18.6{ }^{\circ} \mathrm{C}$ and $19.4{ }^{\circ} \mathrm{C}$, respectively. Chemical treatments were applied on 26 Jan. 1998 by 
Table 1. Solution pH, electrical conductivity (EC) and milliequivalents of calcium carbonate equivalency/L for alkaline chemical treatments (means of 10 replicate measurements).

\begin{tabular}{llrcr}
\hline \hline Chemical & Concentration & $\mathrm{pH}$ & $\mathrm{EC}\left(\mathrm{dS} \cdot \mathrm{m}^{-1}\right)$ & $\begin{array}{c}\text { Milliequivalents } \\
\text { of base/L }\end{array}$ \\
\hline Distilled water control & $\mathrm{N} / \mathrm{A}$ & 6.14 & 0.00 & \\
Supernatant of $\mathrm{Ca}(\mathrm{OH})_{2}$ & $25 \mathrm{~g} \cdot \mathrm{L}^{-1}$ & 12.34 & 7.93 & 22 \\
Flowable Lime & $2.5 \mathrm{~mL} \cdot \mathrm{L}^{-1}$ & 9.56 & 0.08 & 28 \\
$\left(27.75 \% \mathrm{CaCO}_{3}\right.$, & $5 \mathrm{~mL} \cdot \mathrm{L}^{-1}$ & 9.79 & 0.11 & 56 \\
$\left.24.15 \% \mathrm{MgCO}_{3}\right)$ & $10 \mathrm{~mL} \cdot \mathrm{L}^{-1}$ & 9.74 & 0.17 & 113 \\
& $20 \mathrm{~mL} \cdot \mathrm{L}^{-1}$ & 9.68 & 0.28 & 226 \\
& $40 \mathrm{~mL} \cdot \mathrm{L}^{-1}$ & 9.40 & 0.49 & 451 \\
$\mathrm{KHCO}_{3}(99.5 \%)$ & $0.6 \mathrm{~g} \cdot \mathrm{L}^{-1}$ & 8.32 & 0.68 & 6 \\
& $1.2 \mathrm{~g} \cdot \mathrm{L}^{-1}$ & 8.33 & 1.36 & 12 \\
& $2.4 \mathrm{~g} \cdot \mathrm{L}^{-1}$ & 8.44 & 2.68 & 24 \\
& $4.8 \mathrm{~g} \cdot \mathrm{L}^{-1}$ & 8.41 & 5.12 & 48 \\
$\mathrm{KOH}(85 \%)$ & $9.6 \mathrm{~g} \cdot \mathrm{L}^{-1}$ & 8.45 & 9.94 & 1 \\
& $0.056 \mathrm{~g} \cdot \mathrm{L}^{-1}$ & 11.04 & 0.14 & \\
$15 \mathrm{~N}-0 \mathrm{P}-12 \mathrm{~K}$ & $0.56 \mathrm{~g} \cdot \mathrm{L}^{-1}$ & 11.98 & 1.41 & \\
& $50 \mathrm{mg} \cdot \mathrm{L}^{-1} \mathrm{~N}$ & 5.70 & 0.40 & \\
& $100 \mathrm{mg} \cdot \mathrm{L}^{-1} \mathrm{~N}$ & 5.94 & 0.80 & \\
& $200 \mathrm{mg} \cdot \mathrm{L}^{-1} \mathrm{~N}$ & 4.67 & 1.47 & \\
& $400 \mathrm{mg} \cdot \mathrm{L}^{-1} \mathrm{~N}$ & 4.45 & 2.71 & \\
\hline
\end{tabular}

overhead irrigation at a rate of $60 \mathrm{~mL}$ per container (sufficient to bring containers to saturation with minimal leaching). After application, containers were irrigated overhead to container capacity (with minimal leaching) using $40 \mathrm{~mL}$ per container when they reached between $40 \%$ and $50 \%$ container capacity as determined gravimetrically (about every $3 \mathrm{~d}$ ). Distilled water was used to irrigate all treatments except the $15 \mathrm{~N}-0 \mathrm{P}-12 \mathrm{~K}$, which was reapplied at each watering.

Medium-pH and EC were measured using the saturated-medium extract method with distilled water as the extractant (Warncke, 1986). Medium-pH was measured on 10 destructively-sampled containers before the chemical application (day 0) and on four containers $1,7,14,21$, and $28 \mathrm{~d}$ after the application. Medium-pH was measured directly in the saturated medium using an Orion $620 \mathrm{pH}$-meter (Orion Technologies, Beverly, Mass.). Medium-EC was tested before the chemical application and 1 and $28 \mathrm{~d}$ after the application. Medium-EC was measured in the filtered extract using an Orion 130 electroconductivity-meter (Orion Technologies).

The experiment was a completely randomized factorial in which alkaline chemical treatments were applied at several rates, along with a distilled water control, to the peat : perlite medium at six starting-pHs. Each chemical treatment was applied to 20 containers per starting- $\mathrm{pH}$, and 40 containers per starting-pH for the control. Analysis of covariance (ANCOVA) was run for each chemical to test how $\mathrm{EC}$ and $\mathrm{pH}$ were affected by starting-pH, days after application (1-28, analyzed as a continuous variable), the chemical concentration, and their interactions. ANCOVA was initially used to test whether the absolute $\mathrm{pH}$ effect of each chemical was significantly different from the control. We were also interested in change in $\mathrm{pH}(\Delta \mathrm{pH})$ compared with that of the distilled water control at different starting $\mathrm{pH}$ levels. The $\Delta \mathrm{pH}$ was calculated by subtracting each individual $\mathrm{pH}$-measurement from the average $\mathrm{pH}$ for the distilled water control on the corresponding measurement day, and $\Delta \mathrm{pH}$ data were reanalyzed using larly at lower starting-pHs, but throughout the experiment medium-pH from each lime-incorporation rate was statistically different on a given measurement day (Fig. 1). For clarity, the initial lime incorporation rates will be described in this article as different "starting pHs" based on the control $\mathrm{pH}$ at time zero.

Medium-EC of the control pots was not affected by initial lime rate. In all lime treatments, medium-EC did not change between days 0 and $1\left(0.67-0.69 \mathrm{dS} \cdot \mathrm{m}^{-1}\right)$. Medium-EC declined to $0.31 \mathrm{dS} \cdot \mathrm{m}^{-1}$ by day 28 , possibly because of a combination of slight leaching and fertilizer salt stratification. Salt stratification is thought to be caused by evaporation from the root-medium surface (Argo and Biernbaum, 1994, 1995) or by a water front moving into the medium with each irrigation (Yelanich, 1995), and the top 1-cm was removed from soil-test samples in this study.

All alkaline chemical treatments significantly changed medium- $\mathrm{pH}$ compared to that of the control treatment $(P<0.001)$. Therefore, the focus of the remainder of the paper will be on the alkaline chemical effects on $\triangle \mathrm{pH}$. ANCOVA results are summarized in Table 2 . All chemicals had a very rapid effect on media- $\mathrm{pH}$. The $\Delta \mathrm{pH}$ did not change after day 1 (Table 2) except for $\mathrm{Ca}(\mathrm{OH})_{2}$, which declined slightly over time. Charts (Figs. 2-6) therefore present $\Delta \mathrm{pH}$ as least-square means for each chemical treatment over time.

Calcium hydroxide. $\mathrm{Ca}(\mathrm{OH})_{2}$ increased medium-pH by up to $0.49 \mathrm{pH}$ units above that of the control (Fig. 2, Table 2). The $\Delta \mathrm{pH}$ response was greatest at the highest starting$\mathrm{pHs}$, and was only 0.1 units above the control at starting-pH 3.9. The effect on $\Delta \mathrm{pH}$ declined slightly over time, and ANCOVA estimated that $\Delta \mathrm{pH}$ was 0.19 units less on day $28 \mathrm{com}$ pared with day 1 .

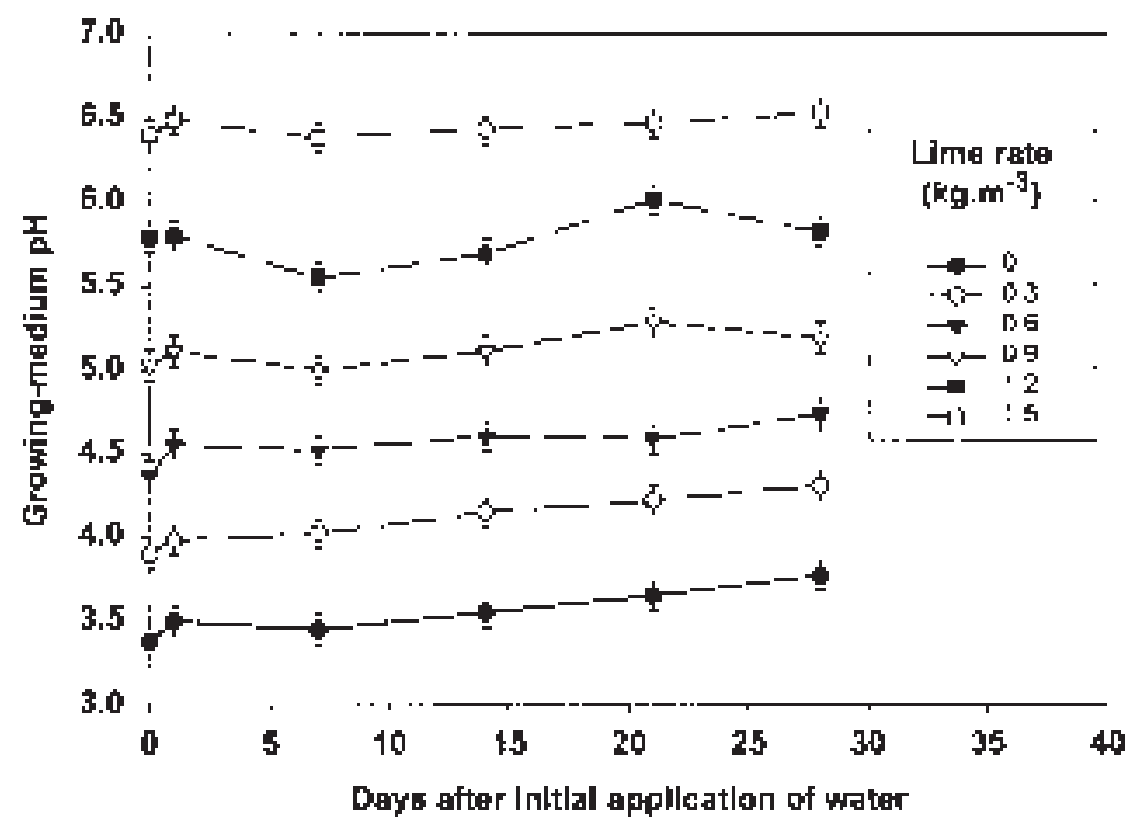

Fig. 1. The pH over a 28-d period following an application of distilled water on day zero and subsequently when the medium reached $50 \%$ container capacity. Each line represents $\mathrm{pH}$ for a peat : perlite medium blended with a single rate of hydrated lime between 0 and $1.5 \mathrm{~kg} \cdot \mathrm{m}^{-3}$. Symbols represent averages of eight replicate medium samples $\pm 95 \%$ confidence intervals. 
There was no effect of the $\mathrm{Ca}(\mathrm{OH})_{2}$ application on medium-EC at day 1. However EC was slightly higher than that of the control (by $0.09 \mathrm{dS} \cdot \mathrm{m}^{-1}$ ) on day 28 (data not shown).

Flowable dolomitic limestone (FDL). FDL significantly increased medium-pH compared with the control, especially at low starting $\mathrm{pH}$ and high concentration (Fig. 3, Table 2). There was no effect of days after application, and averaged across starting-pH and time, the dose response increased from +0.21 to $+1.73 \mathrm{pH}$ units as flowable lime concentration increased from 2.5 to $40 \mathrm{~mL} \cdot \mathrm{L}^{-1}$. FDL had the greatest effect on $\Delta \mathrm{pH}$ at lower starting-pHs. For example, at the recommended rate of $5 \mathrm{~mL} \cdot \mathrm{L}^{-1}$ of the FDL (Bailey, 1996), the $\Delta \mathrm{pH}$ was 2.1 and 0.5 with a starting-pH of 3.4 and 6.4 , respectively.

There was a slight effect of the FDL application on medium-EC at day 1 and 28. However, even at the highest rate of FDL, mediumEC was only $<0.2 \mathrm{dS} \cdot \mathrm{m}^{-1}$ higher than that measured in the control (data not shown).

Potassium bicarbonate. $\mathrm{KHCO}_{3}$ increased medium-pH by up to 2.3 units above that of the control at the highest concentration (Fig. 4, Table 2), and did not change significantly between days 1 to 28 . The dose response averaged across time and starting-pHincreased from +0.22 to $+1.70 \mathrm{pH}$ units as $\mathrm{KHCO}_{3}$ con- centration increased from 0.6 to $9.6 \mathrm{~g} \cdot \mathrm{L}^{-1}$. The $\Delta \mathrm{pH}$ was significantly affected by starting $\mathrm{pH}$, and the greatest response occurred at the highest starting-pHs (5.8 and 6.4). $\mathrm{KHCO}_{3}$ increased medium-EC by up to 0.3 (day 1 ) and $0.4 \mathrm{dS} \cdot \mathrm{m}^{-1}$ (day 28) higher than that measured in the control (data not shown).

Potassium hydroxide. $\mathrm{KOH}$ caused a small but rapid increase in medium-pH (Fig. 5). The dose response was not affected by increasing the concentration of $\mathrm{KOH}$ from 0.056 to $0.56 \mathrm{~g} \cdot \mathrm{L}^{-1}(P=0.07)$, and there was also no effect of time after application $(P=$ $0.42)$. Effect on $\Delta \mathrm{pH}$ was greatest $(+0.32$ averaged across $\mathrm{KOH}$ concentrations) at starting-pH 4.37, which showed a significantly greater response compared with starting-pHs 3.38, 5.79, and 6.40. There was no effect of $\mathrm{KOH}$ on $\mathrm{EC}$ at day 1, but EC from the $0.56 \mathrm{~g} \cdot \mathrm{L}^{-1}$ treatment was $0.1 \mathrm{dS} \cdot \mathrm{m}^{-1}$ higher than the control EC on day 28.

Water-soluble fertilizer. High-nitrate fertilizer $(15 \mathrm{~N}-0 \mathrm{P}-12 \mathrm{~K})$ caused a slight decrease $(-0.09$ to $-0.12 \mathrm{pH}$ units averaged over time) in medium-pHs with a starting- $\mathrm{pH}<5$ (Fig. 6). This decrease in $\mathrm{pH}$ was more pronounced as concentration increased. However, $15 \mathrm{~N}-0 \mathrm{P}-12 \mathrm{~K}$ did not significantly affect medium-pH for starting-pHs of 5.03 and above. On day $1,15 \mathrm{~N}-0 \mathrm{P}-12 \mathrm{~K}$ increased $\mathrm{EC}$ by up to

Table 2. Analysis of covariance summary for the effects of five chemicals on $\Delta \mathrm{pH}$ (mean treatment $\mathrm{pH}$ minus mean control $\mathrm{pH}$ ) for a peat/perlite growing-medium with six starting pHs between 3.4 and 6.4.

\begin{tabular}{lccccc}
\hline \hline Factor & $\mathrm{Ca}(\mathrm{OH})_{2}$ solution & Flowable lime & $\mathrm{KHCO}_{3}$ & $\mathrm{KOH}$ & $15 \mathrm{~N}-0 \mathrm{P}-12 \mathrm{~K}$ \\
\hline Starting $\mathrm{pH}$ & $* *$ & $* * *$ & $* * *$ & $*$ & $* * *$ \\
Concentration & $\mathrm{NA}$ & $* * *$ & $* * *$ & $\mathrm{NS}$ & $*$ \\
Starting pH $*$ conc & $\mathrm{NA}$ & $* * *$ & $* *$ & $\mathrm{NS}$ & NS \\
Days after application & $*$ & $\mathrm{NS}$ & $\mathrm{NS}$ & $\mathrm{NS}$ & NS \\
\hline
\end{tabular}

"Abbreviations: "conc" = concentration, "Starting $\mathrm{pH} "=$ starting $\mathrm{pH}$ at day zero before application. yThere was no concentration factor in the ANCOVA for the supernatant of $\mathrm{Ca}(\mathrm{OH})_{2}$, because there was only one level of the treatment.

Ns, *,**,***N Nonsignificant at $95 \%$ level; significant at the $95 \%, 99 \%$, and $99.9 \%$ levels, respectively.

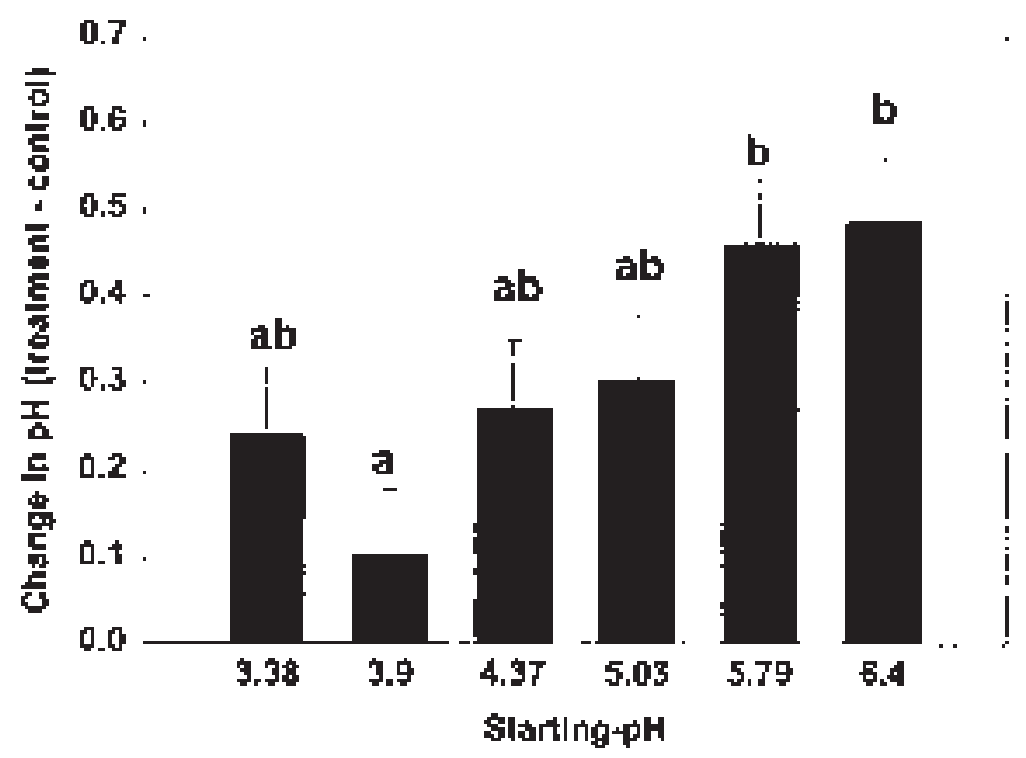

Fig. 2. Effect on medium-pH from an application of the supernatant from $25 \mathrm{~g} \cdot \mathrm{L}^{-1}$ of calcium hydroxide to a medium with six starting-pHs ranging from 3.4 to 6.4 . The chart presents $\Delta \mathrm{pH}$, quantified as the mean $\mathrm{pH}$ from treated media minus the mean $\mathrm{pH}$ of media that received the deionized water control. Bars represent the least-square means over time from 20 replicate samples (four destructivelysampled replicates on each of days $1,7,14,21$, and 28) \pm one sE. Letters above each bar represent Tukey's mean comparison at the $95 \%$ level.
$0.5 \mathrm{dS} \cdot \mathrm{m}^{-1}$ at the highest concentration $(400$ $\left.\mathrm{mg} \cdot \mathrm{L}^{-1} \mathrm{~N}\right) .15 \mathrm{~N}-0-12 \mathrm{~K}$ was the only chemical treatment that was applied with each irrigation, and after $28 \mathrm{~d} \mathrm{EC}$ at $400 \mathrm{mg} \cdot \mathrm{L}^{-1} \mathrm{~N}$ was $1.6 \mathrm{dS} \cdot \mathrm{m}^{-1}$ higher than the control.

\section{Discussion}

Obtaining an acceptable $\mathrm{pH}$ for plant growth is critical for growing quality crops. The alkaline materials tested in this experiment should not be considered as an alternative to pre-plant control of medium-pH, which is based on incorporation of limestone (Nelson, 1998). There are times during the production period, however, when medium-pH falls below an acceptable level and must be readjusted with basic chemicals such as those tested here.

Using a high-nitrate fertilizer had little effect on medium-pH in this experiment, which was expected because plants were not grown in the medium. It is known that applying highnitrate fertilizers to a crop will raise medium$\mathrm{pH}$ over time because of $\mathrm{OH}^{-}$or $\mathrm{HCO}_{3}^{-}$ion secretion by plant roots to balance nitrate uptake (Marschner, 1995). However, there are situations in which the plant has a limited ability to take up $\mathrm{NO}_{3}{ }^{-}$such as newly planted seedlings or stressed plants with little growth. Under these conditions, it would be advisable to use alternative methods for raising medium- $\mathrm{pH}$ besides high-nitrate fertilizers.

The effect of the other materials tested [ $\mathrm{KOH}$, supernatant $\left.\mathrm{Ca}(\mathrm{OH})_{2}, \mathrm{KHCO}_{3}, \mathrm{FDL}\right]$ depended on the concentration applied. One reason that $\mathrm{Ca}(\mathrm{OH})_{2}$ and $\mathrm{KOH}$ had minimal effect on $\Delta \mathrm{pH}$ was that the concentration applied (and base strength in terms of milliequivalents per liter of $\mathrm{CaCO}_{3}$, Table 1) was too low. With $\mathrm{Ca}(\mathrm{OH})_{2}$, the supernatant solution is the maximum concentration obtainable. In other experiments (unpublished data), we have sometimes measured greater $\mathrm{pH}$ response from applications of $\mathrm{Ca}(\mathrm{OH})_{2}$. Elliott (1994) also found variability in saturated solutions of calcium hydroxide, because the quantity of suspended particles varied. Lack of a consistent $\mathrm{pH}$-response is an undesirable characteristic of $\mathrm{Ca}(\mathrm{OH})_{2}$ for use in correcting low medium-pH. With $\mathrm{KOH}$, higher concentrations are obtainable than $\mathrm{Ca}(\mathrm{OH})_{2}$ and increasing concentration above $0.56 \mathrm{~g} \cdot \mathrm{L}^{-1}$ would probably have affected $\Delta \mathrm{pH}$ more than the results reported here. $\mathrm{KOH}$ is a strong base, however, and higher concentrations of $\mathrm{KOH}$ than those tested may be caustic to both plants ( $\mathrm{McNab}$ and Jerie, 1989) and people.

Flowable dolomitic lime and $\mathrm{KHCO}_{3}$ were the most effective materials tested for increasing medium-pH. They were also used at the highest concentration and base strength of the treatments (Table 1) and therefore it would be expected that they would have the greatest effect on $\Delta \mathrm{pH}$. FDL increased medium- $\mathrm{pH}$ to a maximum $\mathrm{pH}$ of $\approx 7.5$, whereas medium-pH reached over 8.5 in some cases following application of $\mathrm{KHCO}_{3}$. This maximum response of FDL may be related to limited limestone solubility at medium-pHs above 7.5 (Lindsay, 1979). Flowable dolomitic lime required constant agitation in the stock solution 


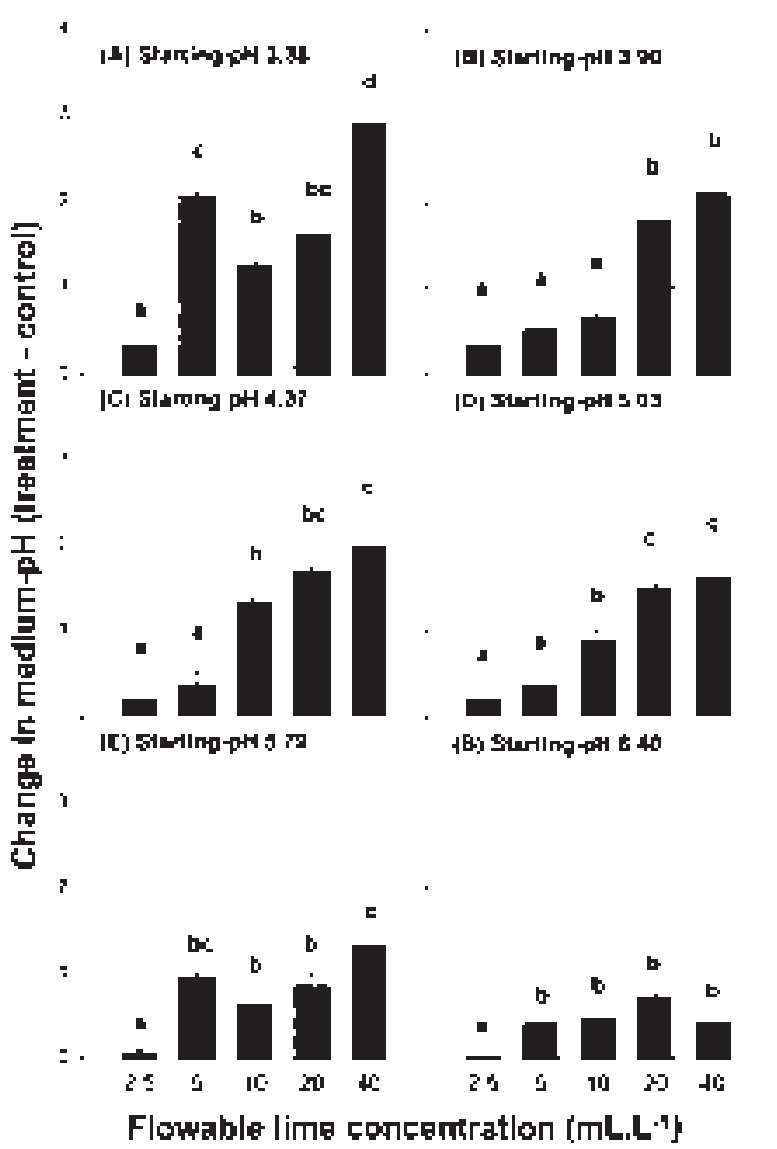

Fig. 3. Effect on medium-pH from an application of flowable dolomitic limestone between 2.5 and $40 \mathrm{~mL} \cdot \mathrm{L}^{-1}$ to a medium with six starting-pHs. The chart presents $\Delta \mathrm{pH}$, quantified as the mean $\mathrm{pH}$ from treated media minus the mean $\mathrm{pH}$ of media that received the deionized water control. Symbols represent least-square means over time (1 to $28 \mathrm{~d}$ after application) from 20 replicate samples (four destructively-sampled replicates on each of days 1 , $7,14,21$, and 28) \pm one SE. Letters above each bar represent Tukey's mean comparison within a starting-pH at the $95 \%$ level.

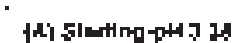

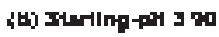

$\mathbf{1}$

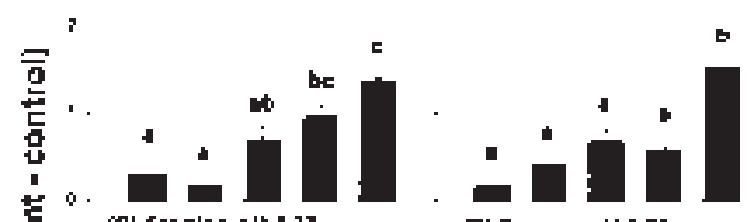

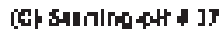

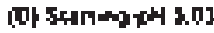
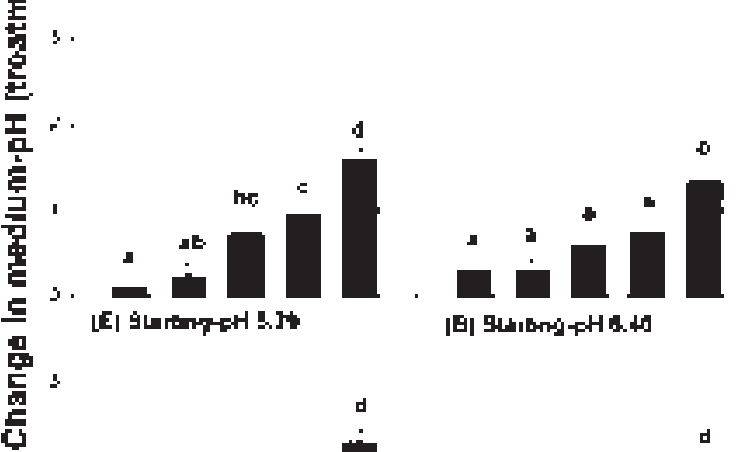

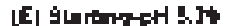

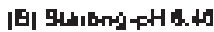

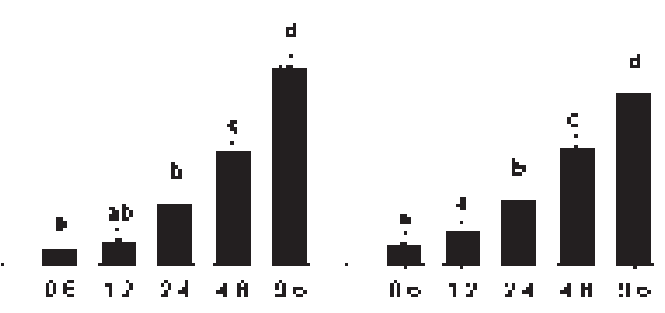

Putagelum bdcarongte concentralion [G-L-1]

Fig. 4. Effect on medium-pH from an application of potassium bicarbonate between 0.6 and $9.6 \mathrm{~g} \cdot \mathrm{L}^{-1}$ to a medium with six starting-pHs. The chart presents $\Delta \mathrm{pH}$, quantified as the mean $\mathrm{pH}$ from treated media minus the mean $\mathrm{pH}$ of media that received the deionized water control. Symbols represent least-square means over time ( 1 to $28 \mathrm{~d}$ after application) from 20 replicate samples (four destructively-sampled replicates on each of days 1, 7, 14, 21, and 28) \pm one SE. Letters above each bar represent Tukey's mean comparison within a starting-pH at the $95 \%$ level.

to maintain a consistent suspension, in addition to significant cleaning of the injector after application. Because of these problems, FDL may not be compatible with certain irrigation methods (flood subirrigation, low volume drip irrigation). In other experiments with FDL (unpublished data), no phytotoxicity to roots or foliage was measured on bedding plants even at $40 \mathrm{~mL} \cdot \mathrm{L}^{-1}$, but at all application rates it was necessary to spray plant foliage with water to remove the lime residue. In comparison, $\mathrm{KHCO}_{3}$ is soluble and can be used with all irrigation methods. Jarrell et al. (1979) did not report damage from $0.2 \mathrm{M}$ solutions of potassium and sodium bicarbonate applied to three foliage species growing in a peat : sand medium. However, in one trial (unpublished data), root damage to geraniums was observed at 4.8 and $9.6 \mathrm{~g} \cdot \mathrm{L}^{-1} \mathrm{KHCO}_{3}$ and foliar damage was observed on soft-tissued bedding plants (for example, celosia at $2.4 \mathrm{~g} \cdot \mathrm{L}^{-1} \mathrm{KHCO}_{3}$ ). Other problems may include high $\mathrm{K}$ levels in the root medium which may interfere with the uptake of other nutrients.

This experiment is a preliminary comparison between alkaline chemicals proposed to raise $\mathrm{pH}$ of soilless medium. The benefit of this research is to evaluate a range of chemi-

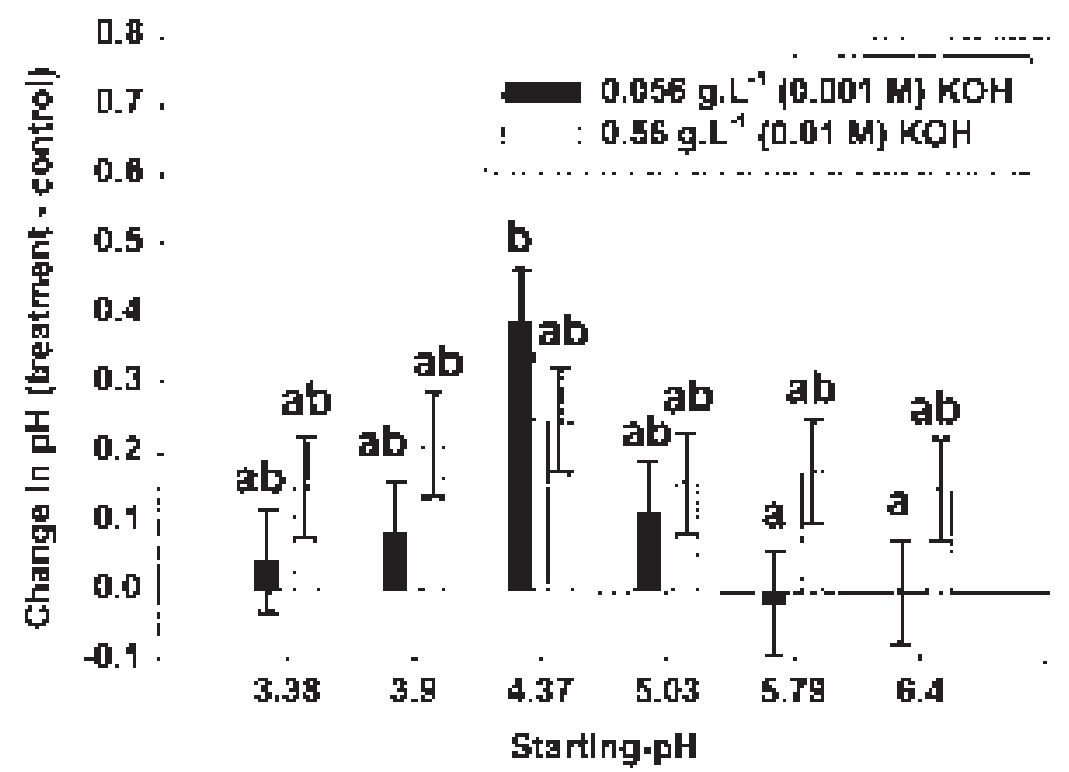

Fig. 5. Effect on medium-pH from an application of $85 \%$ potassium hydroxide at either 0.056 to $0.56 \mathrm{~g} \cdot \mathrm{L}^{-1}$ to a medium with six starting-pHs. The chart presents $\Delta \mathrm{pH}$, quantified as the mean $\mathrm{pH}$ from treated media minus the mean $\mathrm{pH}$ of media that received the deionized water control. Symbols represent least-square means over time ( 1 to $28 \mathrm{~d}$ after application) from 20 replicate samples (four destructively-sampled replicates on each of days 1, 7, 14,21, and 28) \pm one SE. Letters above each bar represent Tukey's mean comparison at the $95 \%$ level. 


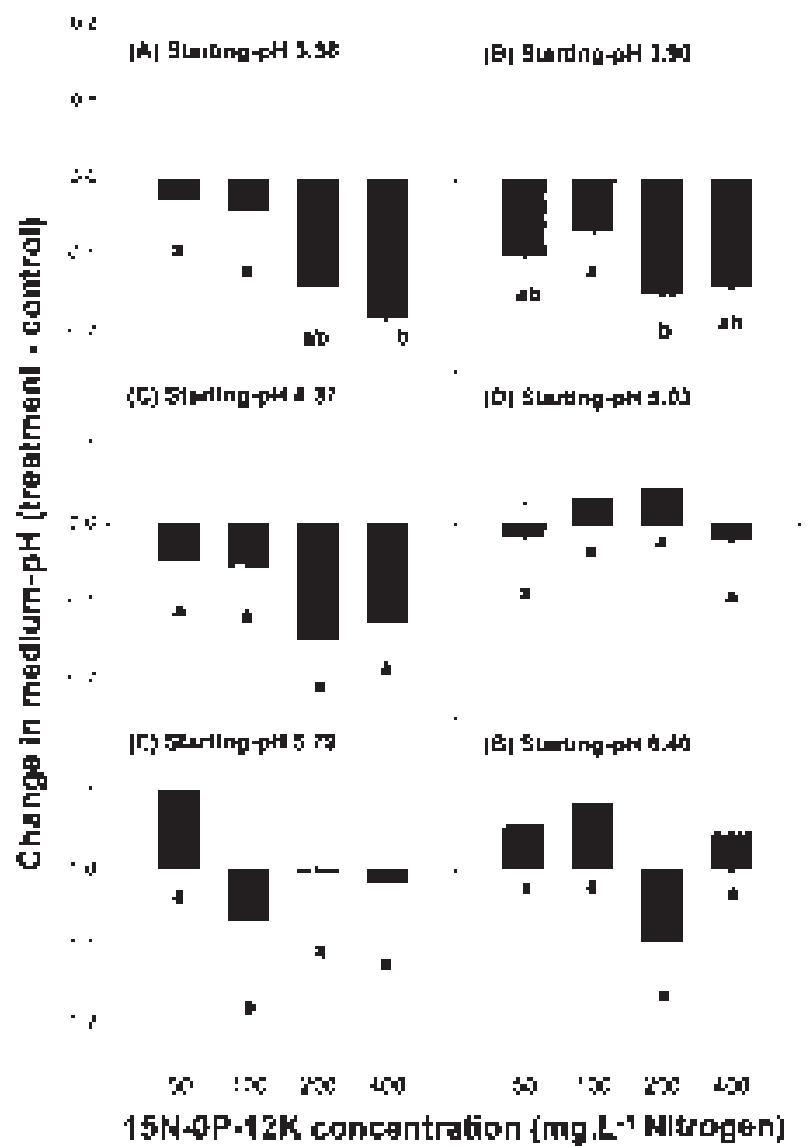

Fig. 6. Effect on medium-pH from an application of $15 \mathrm{~N}-0 \mathrm{P}-12 \mathrm{~K}$ between 50 and $400 \mathrm{mg} \cdot \mathrm{L}^{-1}$ to a medium with six starting-pHs. The chart presents $\Delta \mathrm{pH}$, quantified as the mean $\mathrm{pH}$ from treated media minus the mean $\mathrm{pH}$ of media that received the deionized water control. Symbols represent least-square means over time (1 to $28 \mathrm{~d}$ after application) from 20 replicate samples (four destructively-sampled replicates on each of days $1,7,14,21$, and 28) \pm one SE. Letters below each bar represent Tukey's mean comparison within a starting-pH at the $95 \%$ level.

cals in highly standardized conditions. In addition, application volume $(\approx 0.5$ solution : 1 container volume in this experiment) and or reapplication of the chemical may also be important. Because water-soluble fertilizers, chemicals, medium and plants interact to affect $\mathrm{pH}$, more research is necessary to quantify the effects of these variables to improve recommendations for raising $\mathrm{pH}$ in commercial and research greenhouse environments.

\section{Literature Cited}

Argo, W.R. and J.A. Biernbaum. 1994. Irrigation requirements, root-medium $\mathrm{pH}$, and nutrient con- centrations of Easter lilies grown in five peatbased media with and without an evaporation barrier. J. Amer. Soc. Hort. Sci. 119:1151-1156.

Argo, W.R. and J.A. Biernbaum. 1995. Root-medium nutrient levels and irrigation requirements of poinsettias grown in five root media. HortScience 30:535-538.

Argo, W.R. and J.A. Biernbaum. 1996. The effect of lime, irrigation-water source, and water-soluble fertilizer on root-zone $\mathrm{pH}$, electrical conductivity, and macronutrient management of container root medium with impatiens. J. Amer. Soc. Hort. Sci. 121:442-452.

Bailey, D.A. 1996. Alkalinity, pH, and acidification, p. 69-91. In: D.W. Reed (ed.). Water, medium, and nutrition for greenhouse crops. Ball Publishing, Batavia, Ill.

Biernbaum, J.A. and W.R. Argo. 1995. Effect of root-medium $\mathrm{pH}$ on impatiens shoot micronutrient concentrations. HortScience 30:858. (Abstr.)

Cox, D. 1999. Water-soluble fertilizer affects growth medium $\mathrm{pH}$. Univ. of Massachusetts Ext. Floral Notes 12(3):2-3.

Elliott, G.C. 1994. pH adjustment in soilless medium. Bedding Plants Foundation, Inc. Res. Rpt. F-9407.

Jarrell, W.M., R.A. Shepherd, and R.L. Branson. 1979. Leachate and soil $\mathrm{pH}$ changes in potting mixes treated with $\mathrm{NaHCO}_{3}$ and $\mathrm{KHCO}_{3}$ solutions. J. Amer. Soc. Hort. Sci 104:831-834.

Koranski, D. and R. Kessler. 1996. Detecting plug problems, p. 201-203. In: D. Hamrick (ed.). Grower Talks Plugs II. Ball Publishing, Batavia, Ill.

Lindsay, W.L. 1979. Chemical equilibria in soils. Wiley, New York.

Marschner, H. 1995. Mineral nutrition of higher plants. 2nd. ed. Academic Press, London.

McNab, S.C. and P.H. Jerie. 1989. Effects of potassium bicarbonate on soil acidity resulting from combined irrigation and urea fertilization. Acta Hort. 240:173-176.

Nelson, P.V. 1998. Greenhouse operation and management. 5th ed. Prentice Hall, Upper Saddle River, N.J.

Peterson, J.C. 1981. Modify your $\mathrm{pH}$ perspective. Florist's Rev. Dec. 1981:34-35, 96.

Warncke, D.D. 1986. Analyzing greenhouse growth medium by the saturation extraction method. HortScience 21:223-225.

Yelanich, M.V. 1995. Modeling the concentration of nitrogen in the root zone of container-grown chrysanthemums. PhD Diss., Michigan State Univ., East Lansing. 